\title{
紙パルプエ業へのオゾン利用
}

$$
\begin{array}{rlcc}
\text { クロリンエンジニアズ株式会社 } & \text { 富 } & \text { 家 和 } & \text { 男 } \\
\text { テイサン株式会社 } & \text { 英 和 男 }
\end{array}
$$

\section{Ozone application to the Paper-Pulp Industry}

\author{
Kazuo Tomiie \\ Chlorine Engineers Corp., Ltd. \\ Kazuo Hanabusa \\ Teisan K.K.
}

\begin{abstract}
Ozone application to the Paper-Pulp Industry and recent status of the development of Ozone generation technology.
\end{abstract}

\section{1. 概 要}

紙，パルプ工業におけるオゾンの有効利用について 2,3 の例を紹介し，併せてオゾン発生技術の最近の 進歩改良について解説する。

\section{2. 用途別オソンン発生装置の仕様}

紙パルプ工場の各工程でオゾンが有効利用可能でな いかと思われる $2 ， 3$ の例を表 1 に示した。

抄紙機のラインでスライム発生防止の目的に 1 $\mathrm{mg} / \mathrm{l}$ 以下のオゾン注入で効果が期待される利用例が ある。この用途ではオゾン発生装置はラインの大小に よるが $10 \mathrm{~g} / \mathrm{h}$ から $100 \mathrm{~g} / \mathrm{h}$ 程度の小型でよい。

またクーリングタワー用水の殺菌, 殺藻の目的で循 環冷却水にオゾンを連続的に注入すると効果があると いわれており，これも $1 \mathrm{mg} / \mathrm{l}$ 以下のオゾン注入量で 効果があり，仮に $10,000 \mathrm{t} /$ 日の循環ラインであれば $500 \mathrm{~g} / \mathrm{h}$ 程度のオゾン発生装置で対応できる。また, 廃水の脱色, 脱臭の目的なら平均的に $20 \mathrm{mg} / l$ 程度 のオゾンを必要とし， $10,000 \mathrm{t} /$ 日の処理量で $10 \mathrm{~kg} / \mathrm{h}$ 程度のオゾナイザーを必要とする。古紙再生の脱色漂 白の目的ではオゾン添加量が $3 \sim 5 \mathrm{~kg} / \mathrm{pt}$ といわれて おり, $350 \mathrm{t} /$ 日のプラントの場合約 $70 \mathrm{~kg} / \mathrm{h}$ のオゾン 発生装置が必要となる。

最近, 最大の関心がもたれている $\mathrm{KP}$ 漂白にオゾ ンを適用する場合は $5 \mathrm{~kg} / \mathrm{pt}$ とし $1,000 \mathrm{t} /$ 日のプラン トを想定すると $200 \mathrm{~kg} / \mathrm{h}$ 程度の大型のオゾン発生装
置が必要となる。

一般にオゾン発生装置は発生量によって小型, 中型, 大型, 及び超大型に分類できる。夫々単機発生容量と して,

小 型……100 g/h 以下

中 型……100 g/h $1 \mathrm{~kg} / \mathrm{h}$

大 型 $\cdots \cdots \cdot 1 \mathrm{~kg} / \mathrm{h} \sim 50 \mathrm{~kg} / \mathrm{h}$

超大型 $\cdots \cdots . .50 \mathrm{~kg} / \mathrm{h}$ 以上

中型以下では装置ができる限り簡単で安全に設計さ れていて, 無人自動運転が可能であり, 故障しても簡 単に修理できることが要求される。用途例としてプー ル用 $50 \mathrm{~g} / \mathrm{h}$ 以下, 屎尿処理用 $1 \mathrm{~kg} / \mathrm{h}$ 以下, 半導体で の用途は $500 \mathrm{~g} / \mathrm{h}$ 以下が主である。

大型は上下水道で使用され，システムとしての制御 性や電力消費の低減などが要求される。もちろん安全 性は最も重要な使用条件であるが, 上下水道では連続 使用が前提であり, 緊急対策対応やメンテナンスサー ビスが採用時の重要な要求条件となる。

超大型の $50 \mathrm{~kg} / \mathrm{h}$ 以上のオゾン発生設備になると 年間の電力消費が大きいので省エネルギー型のオゾン 発生装置が要求される。パルプ漂白の用途ではオゾン 濃度の高いもの $\left(10 \mathrm{wt} \%, 148 \mathrm{~g} / \mathrm{Nm}^{3}\right)$ 以上が要求 され, 安全性やシステムの制御性,メンテナンス性な ど要求仕様が高度化する。

オゾンの利用を促進するには小型, 中型から大型, 超大型とそれぞれの目的用途別にオゾン発生技術が進 歩改良され，コストの引き下げ（設備費とランニング 
表 1 用途別オゾン発生装置

\begin{tabular}{|c|c|c|}
\hline & オゾン発生量 & 使 \\
\hline 小型オゾン発生装置 & $10 \mathrm{~g} / \mathrm{h} \sim 100 \mathrm{~g} / \mathrm{h}$ & $\begin{array}{l}\text { スライム発生防止用に約 } 0.5 \mathrm{mg} / l \text { のオゾンを注入すると効果発 } \\
\text { 揮 }\end{array}$ \\
\hline 中型オゾン発生装置 & $100 \mathrm{~g} / \mathrm{h} \sim 1 \mathrm{~kg} / \mathrm{h}$ & $\begin{array}{l}\text { クーリングタワー用水の殺菌、殺藻に循環冷却水ラインに連続的 } \\
\text { に約 } 0.5 \mathrm{mg} / l \text { のオゾンを注入すると効果を発揮 }\end{array}$ \\
\hline 大型オゾン発生装置 & $1 \mathrm{~kg} / \mathrm{h} \sim 50 \mathrm{~kg} / \mathrm{h}$ & $\begin{array}{l}\text { 廃水の脱色, 脱臭, COD 削減に約 } 20 \mathrm{mg} / l \text { のオゾンを注入する } \\
\text { と効果発揮。 } \\
\text { パルプの OZP 多段漂白, 古紙漂白, 半晒パルプの漂白に約 } 5 \\
\mathrm{~kg} / \mathrm{pt} \text { のオゾン注入で効果発揮 }\end{array}$ \\
\hline 超大型オゾン発生装置 & $50 \mathrm{~kg} / \mathrm{h} \sim$ & 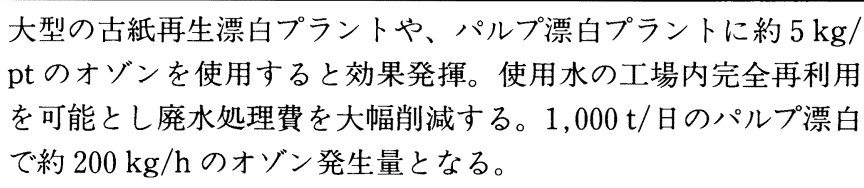 \\
\hline
\end{tabular}

コストの引き下げ）が実現し，はじめて顧客の要求に 応じることが可能となる。

用途によって空気を用いる場合と酸素を用いる場合 とがあり，夫々の特長を有している。パルプの漂白に は酸素を用い高濃度のオゾンを発生させることでコス トの引き下げに成功した。

\section{3. オゾン発生技術 ${ }^{11}$}

用途別に時間当りの発生量がグラム単位の小型のも のから数 $100 \mathrm{~kg}$ 単位の超大型の発生装置が要求され ている。

小型や中型の装置はガラス誘電体に商用周波数 $(60 / 50 \mathrm{~Hz})$ で $10 \mathrm{kV}$ 以上の電圧を印荷する。

大型の発生装置では発生効率を高めるため, インバ 一夕技術により中周波数 $(600 \sim 1,000 \mathrm{~Hz})$ に変換し て $10 \mathrm{kV}$ 以下の電圧を印荷する。

印荷電圧が高いとガラス誘電管の破損や電力消費の ロスがあり，周波数を中周波に增加させることで印荷 電圧を下げることに成功した。オゾンの発生量は 50 $\mathrm{Hz}$ を $1,000 \mathrm{~Hz}$ にすることで同一印荷電圧であれば, 理論的には 20 倍になる。

ガラス誘電体についての材質や品質の改良がすすみ, セラミックス誘電体も使用されるようになった。一方 オゾン発生のシステムとしては空気を使用する場合は 露点を $-60^{\circ} \mathrm{C}$ 以下にする乾燥技術が確立し，オゾン発 生効率の改善と連続長期安定運転を可能とした。酸素 を使用するオゾン発生技術も進歩し高濃度オゾンを高 効率で発生せしめ, 設備費の低減とランニングコスト の大部分を占める電力消費の低減にも成功した。酸素
発生装置にPSA が採用され酸素発生コストが大幅に 低減された。これらの改良技術によってさらに需要が 拡大寸るという良い循環がはじまったと言える。

図 1 は最近のオゾン発生技術の進歩を示すもので 3 の曲線は $10 \mathrm{wt} \%$ のオゾン濃度で電力消費は従来技術 の $6 \mathrm{wt} \%$ オゾン濃度発生と同等である。しかも単機 容量で $50 \mathrm{~kg} / \mathrm{h}$ のオゾン発生が可能であり, パルプ 漂白にオゾンを採用する期待に応えた。

\section{4. 冷却水システムへのオソンンの適用 ${ }^{2)}$}

冷却水システムには一過式と循環式があり, オゾン の適用は循環式冷却システムが対象となる。スライム 発生防止としては微生物, 藻類である。オゾンを適用 した場合の期待効果としては

1） スライム発生防止：オゾンの強力な酸化力によ つて殺菌, 殺藻, 生物付着防止が可能である。

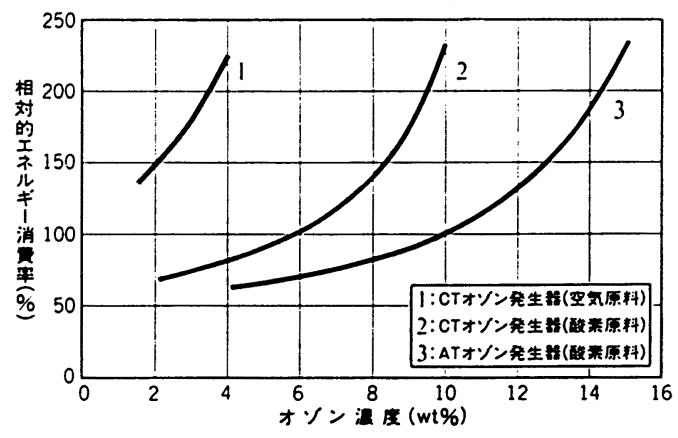

図 1 同一条件下に於けるオゾン濃度と相対的電力 消費率（\%）（冷却水温度 $15^{\circ} \mathrm{C}$ ） 
2）マイクロフロキュレーション効果：閉鎖系循環 冷却水システムでオゾンを注入すると有機物の 低分子化合物やカルシウムなどがフロックを形 成しフィルターでのろ過除去が容易となる（濁 質成分の除去)。

3）塩素に比較して二次污染がない半減期が短く残 留性がない。

4）空気を原料としてオンサイトで生成する。

5）冷却水 $1 \mathrm{~m}^{3}$ 当り $0.05 \mathrm{~g}$ のオゾン注入でスライ ム, 藻類の発生が防止できた。

\section{5. オゾンによる脱色 ${ }^{3)}$}

図 2 に示すようにオゾンの分子構造は 4 つの極限構 造の混成状態と考えられ, オゾンは発色団である二重,
三重結合をもつ化合物とよく反応し結合を切ったり， 芳香環を開裂するなど酸素付加反応を起こす。

図 3 に脱色反応の 1 例を示したが, 着色水の発色団 はオゾンにより二重結合を失って，光を吸収しなくな

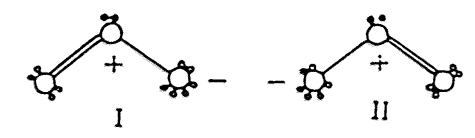

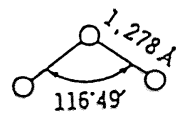

(a)

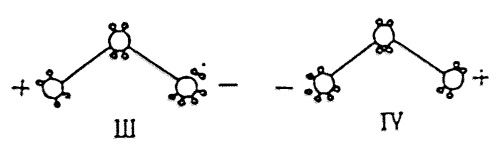

(b)
図 2 オゾンの分子構造

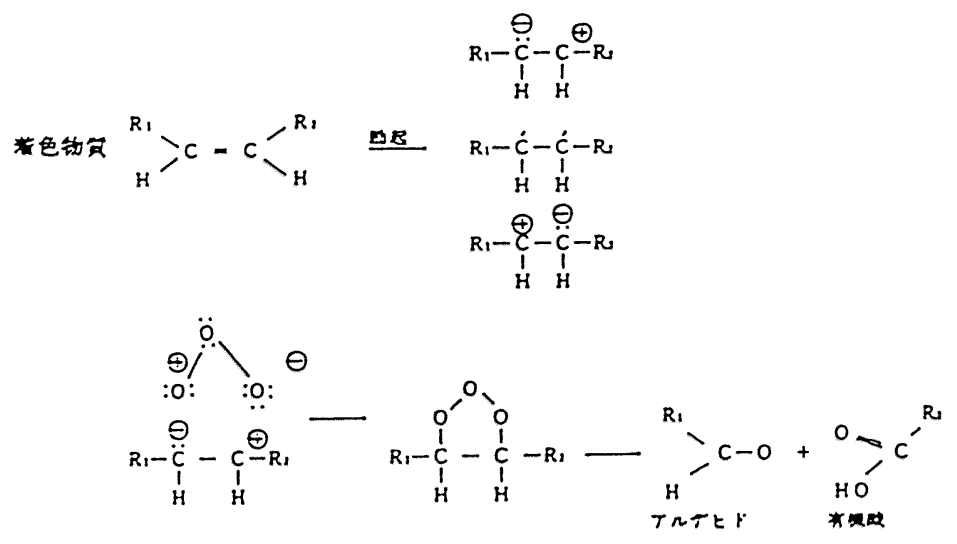

図 3 オゾンによる脱色反応

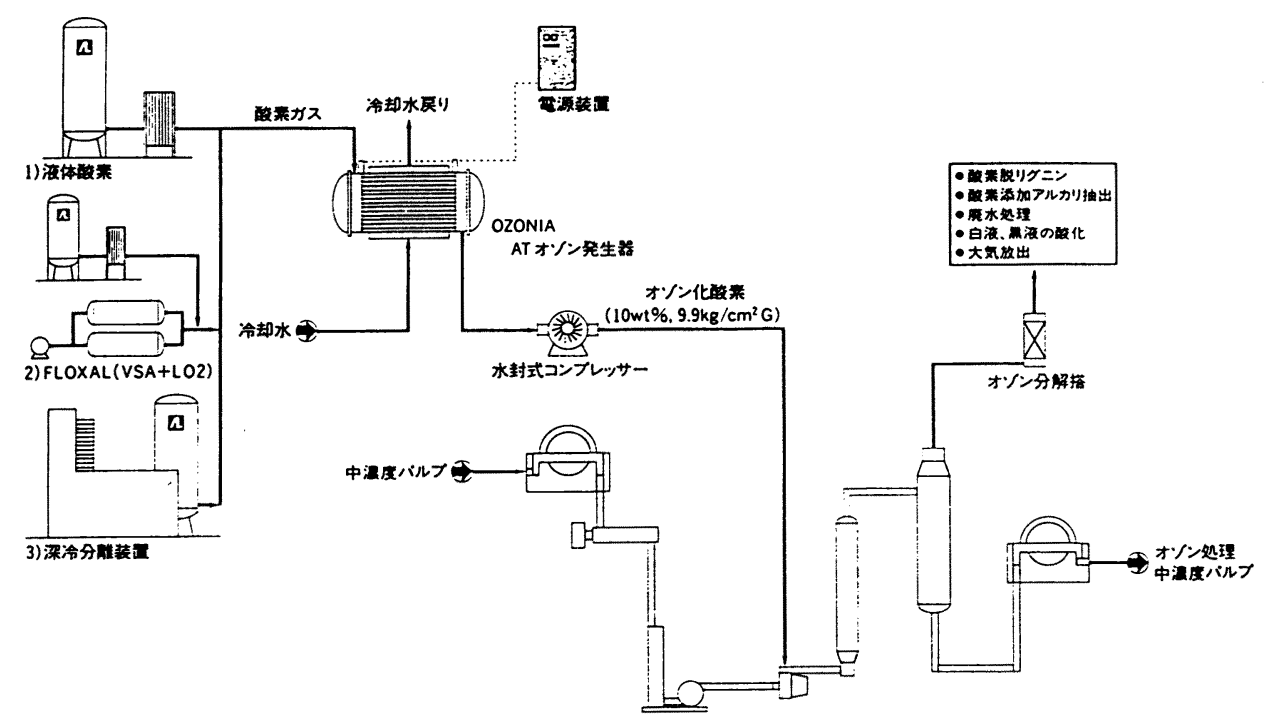

図 4 代表的中濃度パルプオゾン漂白フローシート 
りその結果脱色が生じる。

オゾン脱色への影響因子としては

(1) SSの存在によりオゾンが SS と反応しオゾン の消費を増加させ脱色効果を悪くする。 SSの 前処理除去を必要とする。

（2）CODやその他の還元剤の存在でオゾンを消費 方る。

(3) $\mathrm{pH}$ の影響を受けるので最適 $\mathrm{pH}$ を確認する必 要がある。

\section{6. オゾンによる古紙の再生処理}

平成 3 年に本州製紙より出願された古紙のオゾン処 理による再生方法は古紙を少なくとも $20 \%$ 以上の水 分を含むスラリー状とし，オゾンを反応せしめ着色紙， 蛍光増白紙の脱色を行い再生すると記述されている。

その他 M. Muguet はオゾンと過酸化水素を組み合 わせた古紙の再生の可能性を指摘している。オゾンで 発色団を開裂し, 過酸化水素で完全に切断し脱色を完 成させると推定する。

表 2 オゾン漂白工場 平成 6 年 10 月現在

\begin{tabular}{|c|c|c|c|c|}
\hline $\begin{array}{l}\text { MILL } \\
\text { 工 場 }\end{array}$ & $\begin{array}{l}\text { LOCATION } \\
\text { 場 所 }\end{array}$ & $\begin{array}{c}\text { OZONE } \\
\text { CAPACITY } \\
\text { オゾン能力 }\end{array}$ & $\begin{array}{l}\text { START-UP } \\
\text { 操業開始 }\end{array}$ & $\begin{array}{l}\text { COMMENTS } \\
\text { コメント }\end{array}$ \\
\hline LENZING AG & $\begin{array}{l}\text { Lenzing } \\
\text { AUSTRIA }\end{array}$ & $\sim 30 \mathrm{~kg} / \mathrm{h}$ & 1992 & $\begin{array}{l}365 \mathrm{~T} / \mathrm{d} \text { hardwood dissolving sulphite } \\
\text { pulp for viscose manufacturing; } \\
\text { EPZP sequence; Ozone at } 10 \% \\
\text { concentration; M.C. }\end{array}$ \\
\hline $\begin{array}{l}\text { OUNION CA- } \\
\text { MP }\end{array}$ & $\begin{array}{l}\text { Franklin, Va } \\
\text { USA }\end{array}$ & $280 \mathrm{~kg} / \mathrm{h}$ & 1992 & $\begin{array}{l}1,000 \mathrm{~T} / \mathrm{d} \text { softwood kraft pulp; } \\
\text { OZED sequence; ozone at } 6 \% \text {; } \\
\text { H.C. }\end{array}$ \\
\hline SODRA CELL & $\begin{array}{l}\text { Mönsteras } \\
\text { SWEDEN }\end{array}$ & $200 \mathrm{~kg} / \mathrm{h}$ & 1992 & $\begin{array}{l}\text { TCF hardwood kraft pulp (1992) } \\
\text { and softwood pulp (1993); M.C. }\end{array}$ \\
\hline $\begin{array}{l}\text { OSTORA } \\
\text { BILLERUD }\end{array}$ & $\begin{array}{l}\text { Skoghall } \\
\text { SWEDEN }\end{array}$ & $42 \mathrm{~kg} / \mathrm{h}$ & 1992 & $\begin{array}{l}\text { softwood kraft pulp; ozone at } \\
10 \% \text { concentration; M.C. }\end{array}$ \\
\hline $\begin{array}{l}\text { OMoDo PAP. } \\
\text { ER }\end{array}$ & $\begin{array}{l}\text { Husum } \\
\text { SWEDEN }\end{array}$ & $200 \mathrm{~kg} / \mathrm{h}$ & 1993 & $\begin{array}{l}\text { Hardwood kraft line } 300.000 \mathrm{~T} / \mathrm{y} ; \\
\text { ozone at } 10 \% \text { concentration; M.C. }\end{array}$ \\
\hline WISAFOREST & $\begin{array}{l}\text { Pietarsaari } \\
\text { FINLAND }\end{array}$ & $100 \mathrm{~kg} / \mathrm{h}$ & 1993 & $\begin{array}{l}\text { Production-scale triais on hardwood } \\
\text { kraft pulp; ozone at } 7 \% ; \mathrm{M} . \mathrm{C} \text {. }\end{array}$ \\
\hline $\begin{array}{l}\text { OMETSA-BO- } \\
\text { TNIA }\end{array}$ & $\begin{array}{l}\text { Kaskinen } \\
\text { FINLAND }\end{array}$ & $300 \mathrm{~kg} / \mathrm{h}$ & 1993 & $\begin{array}{l}\text { Hardwood/softwood kraft line, } \\
420.000 \mathrm{~T} / \mathrm{y} \text {; ozone at } 10 \% \text { con- } \\
\text { centration }\end{array}$ \\
\hline $\begin{array}{l}\text { PETTERSON } \\
\text { SEFFLE }\end{array}$ & $\begin{array}{l}\text { Säffle } \\
\text { SWEDEN }\end{array}$ & $\sim 30 \mathrm{~kg} / \mathrm{h}$ & 1994 & 132 T/d sulphite pulp ; M.C. \\
\hline$\bigcirc \mathrm{SCA}$ & $\begin{array}{l}\text { Östrand } \\
\text { SWEDEN }\end{array}$ & $180 \mathrm{~kg} / \mathrm{h}$ & 1995 & $320,000 \mathrm{~T} / \mathrm{y} ;$ ozone at $12 \%$; H.C. \\
\hline $\begin{array}{l}\text { OPONDA RO- } \\
\mathrm{SA}\end{array}$ & NORTH AMERICA & $68 \mathrm{~kg} / \mathrm{h}$ & 1995 & Recycling Paper; ozone at $10 \%$ \\
\hline OSAPPI & $\begin{array}{l}\text { Ngodwana } \\
\text { SOUTH AFRICA }\end{array}$ & $270 \mathrm{~kg} / \mathrm{h}$ & 1995 & $425,000 \mathrm{~T} / \mathrm{y} ;$ ozone at $10 \sim 13 \%$ \\
\hline
\end{tabular}

注記：○印の工場でオゾニア社製のオゾン発生器が採用されております。 
北大の寺沢教授によると ${ }^{3)}$ オゾンは求電子試薬であ り図 3 に示した反応でオレフィンや芳香環などの二重 結合のパイ電子と反応しパルプに含まれる発色団と速 やかに反応し共役結合を切断, 分解する。

反応系中にパラキノン，オルソキノン等の発色団が 副生する。これら副次的に生成した発色団はそれ自身 求電子的性格がありオゾンとの反応性は低い。さらに オゾンで脱色をすすめると械維を傷めることになる。 オゾンの漂白はカッパー価 3.5 までとし，その後は 過酸化水素等の求核試薬で残存する発色団を分解する と漂白がすすみ色戻りがなくなるとしている。

\section{7. パルプ漂白へのオソンの適用}

パルプ漂白に塩素又は塩素系の薬品を使用すること に対する反省, 見直しの気運が高まり, 代替技術とし て酸素及びオゾン, 過酸化水素を漂白の薬品として使 用する工場が北欧，北米で増加している。

酸素漂白で塩素系漂白凨の使用量を削減する OXY

Pulp 法, 塩素は使用せず二酸化炭素を使用する ECF
(Elemental Chlorine Free) 法, 全く塩素や塩素系 漂白鼡を使用しない TCF (Totally Chlorine Free) 法があり TCF 法のパルプ漂白工場が今後増加すると 予想されている。排水処理問題の解決で経済性の点で もすぐれているといわれており, 得られるパルプの品 質も安定しているといわれている。表 2 が最近のオゾ ンを採用したパルプ漂白工場の一覧であり図 4 が代表 的中濃度パルプのオゾン漂白フローシートである。

\section{文献}

1）英和男, 富家和男：酸素使用高濃度オゾン発生装 置について。第 3 回日本オゾン協会年次研究講演 会講演集, 日本オゾン協会, 1994, 京都

2) R. Wellaner, A. Kyas: Ozone as Biocide for cooling Water System. 8th Ozone World Congress Sep. 1987 Zurich (Swiss)

3）寺沢実, 小島康夫 : オゾンでのパルプ漂白。第 1 回オゾンに関するセミナーテキスト, 日本オゾン 協会, 1991 